\title{
Effect of feeding liquid milk supplement on litter performances and on sow back-fat thickness change during the suckling period
}

\author{
G. Novotni-Dankó ${ }^{1}$, P. Balogh ${ }^{2}$, L. Huzsvai ${ }^{2}$, and Zs. Gyốri ${ }^{1}$ \\ ${ }^{1}$ University of Debrecen (UD), Faculty of Agricultural and Food Sciences and Environmental Management, \\ Department of Animal Breeding, Debrecen, Hungary \\ ${ }^{2}$ UD, Faculty of Economics and Business, Department of Research Methodology and Statistics, \\ Debrecen, Hungary
}

Correspondence to: G. Novotni-Dankó (novotnine@agr.unideb.hu)

Received: 27 February 2015 - Revised: 08 June 2015 - Accepted: 16 June 2015 - Published: 29 June 2015

\begin{abstract}
The aim of the present study was to investigate the effect of liquid milk supplement on litter performance (weight development of the piglets, weaning weight and mortality) and on sow back-fat thickness change during the suckling period.

Data were collected from 150 litters, with the weight of a total of 1709 piglets measured at birth, at 14 days of age and at weaning (28 days), respectively. Sow $(n=150)$ back-fat depth was measured the day before farrowing, 14 days after farrowing and at weaning. In the control group $(n=363)$, the piglets were suckled and got pre-starter feed from day 10. In the four experimental groups (MS1; MS2; MS2 and MS4; $n=1346$ ), the piglets received additional milk replacer in various concentrations from the 10th day of life. While there were no significant differences in birth weight between the control and experimental groups, we did find significant differences between the 14-day weights and weaning weights. The milk supplement significantly reduced mortality compared to the control (11.6 vs. $4.9 ; 5.9,8.9 ; 8.3 \%)$. However, there were no statistically significant differences between litter homogeneity data, based on the CV\% of piglet weight. Three experimental groups (MS1, MS2 and MS4) were more homogenous compared to the control group at weaning (25.3 vs. 20.9; 20.3; $20.3 \mathrm{CV} \%$ ). Based on the examination of sow back-fat thickness reduction, there were significant differences between the control (C) and MS3 groups ( 7.61 vs. $5.57 \mathrm{~mm}$ reduction, $P<0.05)$ during the suckling period. These results demonstrate the advantage of milk replacer on weaning weight. Litter homogeneity, piglet mortality and back-fat thickness of the sows were affected by providing milk replacer to the piglets during the suckling period.
\end{abstract}

\section{Introduction}

Sow milk production is the major factor limiting pig growth prior to weaning. Weaning weight is quite variable from litter to litter and much of this variation is due to the quantity of milk produced by sows. Several factors cause a variation in milk production, e.g., number of parity, in general. High environmental temperatures during lactation decrease milk yield, litter growth and reproductive performances. Milk production depends on the sow's nutritional status. For example, supplementing diets with L-carnitine during lactation sows resulted in higher milk yields than the controls for days 11 and 18 of lactation. Highly significant breed difference was found in the amount of milk produced and in the average size of the litter suckled, whereas a significant difference was found in the average litter weight at the end of the suckling period (Allen and Lasley, 1960; King et al., 1997; Ramanau et al., 2004; Spencer et al., 2003).

However, most suckling pigs from litters of 10 or more commonly weigh only $7-8 \mathrm{~kg}$ at 4 weeks, indicating that there is a shortfall in milk supply at the udder. The potential for growth and the availability of sow's milk begin to diverge at about 20 days of age; therefore, it may be assumed that, from this point on, supplementary feeding is beneficial. 
Generally, suckling pigs may begin to eat trivial amounts of supplementary feed at around 10 days of age (Kyriazakis et al., 2006).

The neonatal growth period of the pig, from birth to weaning, represents a critical phase in pork production. Genetic selection for larger litter size (from $\leq 11$ to $\geq 16$ piglets) has also resulted in a reduction in mean piglet birth weight, increased within-litter variation in birth weight and a rise in the proportion of low-birth-weight piglets $(<1.0 \mathrm{~kg})$ within these large litters. Below $1.0 \mathrm{~kg}$ birth weight, more than $11 \%$ of piglets are stillborn and more than $17 \%$ of such low-birthweight piglets die within the first $24 \mathrm{~h}$. Despite a low number of small animals still alive at weaning, the higher the birth weight is, the higher the average daily gain over the suckling, the post-weaning and the growing-finishing periods. The growth potential of a suckling pig may be limited by several factors; heavier piglets are able to remove more milk from the anterior mammary glands of lactating sows and consequently grow faster than lighter piglets (King et al., 1997; Mitchell et al., 2012; Quiniou et al., 2002).

Genetic improvement of the prolificacy of sows during the 2 last decades has resulted in an indirect increase in milk production. Currently, the growth rate of a litter can reach $3 \mathrm{~kg} \mathrm{~d}^{-1}$, which corresponds to an estimated milk yield of about $12 \mathrm{~kg} \mathrm{~d}^{-1}$. In improving reproductive performances, breeders focus on increasing the lactation performance of sows, simultaneously. However, if the milk production meets the needs of the litter, it has a positive effect on the piglets' later feed consumption behavior, as well as in their weight gain. A positive correlation was found between the amount of milk produced by a sow and the amount of creep feed consumed by her litter, with the piglets of those sows producing the most milk consuming the most creep feed (Allen and Lasley, 1960; Renaudeau and Noblet, 2001).

Skorjanc et al. (2007) indicated that neither milk production after the second week of lactation nor consumption of creep feed is sufficient enough to cover the nutrition needs of fast-growing piglets. There is still a lack of optimization of nutrient in the pre-weaning period, especially for heavier piglets with their higher growth potential.

Weaning weight is predictive of overall pig performances. As the swine industry moved to earlier weaning ages, the need to increase weaning weight has become more critical. The study of Azain et al. (1996) demonstrated that supplemental milk replacer resulted in a significant increase (main effect) in weaning weight and total litter weight. Milk replacer also reduced the difference normally observed in piglet weaning weight between primiparous and multiparous sows (Spencer et al., 2003).

Low piglet weight at weaning implies a loss of income for the farmer and could influence the welfare of the affected animals negatively. Several factors, in combination, determine the weight gain of a pig between birth and weaning, e.g., the herd/sow, the pen, the litter and the piglets (Johansen et al., 2004). Season has shown to strongly affect weaning weight as well, with lower weaned weights typically seen in summer (Knecht et al., 2015). Sow fertility increases with increasing back-fat thickness. Sows with a thicker layer of back fat achieve better litter performance and more litter in the course of their lives. The increasing back-fat thickness of sows with a higher number of parturitions indicates a positive effect on average longevity. The analysis of the number of all live-born and weaned piglets again corroborated the fact that fertility increased linearly (Cechova and Tvrdon, 2006). Maintaining adequate body tissue reserves throughout a sow's lifetime is thought to be important to maximize herd productivity. If primiparous sows mobilize more than $12 \%$ of their body protein mass during lactation, then subsequent ovarian function and, in turn, reproductive performance will be negatively affected, in addition to decreased litter growth rate (Clowes et al., 2003).

Although the milk production of hybrid sows has increased in the last decades, many environmental factors affect their actual performances. Use of a supplemental milk replacer can be an appropriate solution to ward off uncertainty, equalize milk quantity based on piglet appetite and to ultimately enlarge weaning weight. Milk replacer usage may also improve reproductive performance by diminishing the negative energy balance of the sow during lactation.

The aim of the present study was to investigate the effects of feeding liquid milk supplement on litter performances (weight development of the piglets, weaning weight, mortality and litter's homogeneity) and on sow back-fat thickness change during the suckling period.

\section{Material and methods}

\subsection{Animals}

Data were collected from 150 farrowings of Large White $\times$ Landrace hybrid sows, primiparous vs. multiparous (October and November 2013). The weights of a total 1709 piglets were individually weighed.

The sows were kept in groups during gestation and moved into a farrowing house ( 30 sows/unit) using crates with solid concrete floors, 3 or 4 days before the expected date of farrowing. On the day of parturition, they were offered $2.0 \mathrm{~kg} \mathrm{day}^{-1}$ of a lactation diet containing

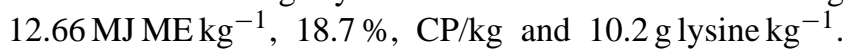
Thereafter, daily feed allowance was increased by $0.5 \mathrm{~kg}$ until ad libitum intake was achieved.

On day 2 postpartum, all piglets received industry standard processing (tail docking, ear notching, iron injections and castration of males). The daily consumption of the milk supplementation was measured in the farrowing house. 


\subsection{Experimental groups}

There were five groups:

- a control group ( $C ; n=363$ piglets) in which the piglets were suckling and received pre-starter feed, but did not get milk supplement;

- MS1 group ( $n=347)$ in which the piglets got milk supplement (MS) in $10.7 \%$ weight percentage solution: $1.2 \mathrm{~kg}$ dry milk powder was added to $10 \mathrm{~L}$ water;

- MS2 group $(n=305)$ in which the piglets got MS in $13 \%$ weight percentage solution: $1.5 \mathrm{~kg}$ dry milk powder was added to $10 \mathrm{~L}$ water;

- MS3 $(n=347)$ in which the piglets got MS in $14.5 \%$ weight percentage solution: $1.7 \mathrm{~kg}$ dry milk powder was added to $10 \mathrm{~L}$ water;

- MS4 $(n=347)$ in which the piglets got MS in $16.6 \%$ weight percentage solution: $2.0 \mathrm{~kg}$ dry milk powder was added to $10 \mathrm{~L}$ water.

The piglets in the control group were suckling from birth till weaning, and they got pre-starter feed from day 10 (BiominProfi Start G3, Biomon $\mathrm{GmbH}$, Austria; protein: $20 \%$, fat: $8 \%$, lys: $1.45 \%$ ) ad libitum.

The piglets in experimental groups were fed with liquid milk replacer from day 10 after birth as well as suckling and consuming pre-starter feed. Liquid milk replacer was prepared by hand-mixing. The milk powder (SanAmmat F, Sano GmbH, Germany; contains $21.5 \%$ protein, $18 \%$ fat, $1.7 \%$ lysine, $\mathrm{Ca}=0.8 \%, \mathrm{P}=0.7 \%$ ) was admixed to $40{ }^{\circ} \mathrm{C}$ water in the necessary concentration. The volume of the central tank is $100 \mathrm{~L}$, which was filled with the liquid milk replacer. The liquid milk supplement was charged according to the piglets' appetite. The tank and the milk feeders were washed and fresh milk replacer was added every day. The residuum was measured and taken away from the daily portion and the net consumption was registered.

The weights of a total 1709 piglets were individually weighed at birth, at 14 days of age and at weaning (28 days), respectively, using an electronic scale.

Sow back-fat depth was measured $6 \mathrm{~cm}$ from the midline at the level of the last rib with an A-Mode ultrasonic Renco Lean-Meater ${ }^{\circledR}$ SERIES 12 . We followed the changes in the sows body condition by measuring back-fat thickness three times: on the day before farrowing, 10 days after farrowing and at weaning $(28 \mathrm{~d})$.

\subsection{Statistical analysis}

Data were analyzed using descriptive statistics, one-way ANOVA, chi-square test and repeated measure mixed effect models in R program (R Core Team, 2014). Multiple comparison tests were done with the Duncan's new multiple range test (Mendiburu, 2014). Normality of residuals was tested visually by normal plot and by the Shapiro-Wilk $W$ test. Homogeneity of variance was checked by plots of the standardized residuals against predicted values. To account for the repeated measures per piglet (across time: period), the individual was nested within treatment and treated as random effect in the analysis. The model included fixed effects of treatment $\left(\operatorname{Tr}_{i}\right)$, time $\left(T_{j}\right)$ and treatment $\times$ time $(\operatorname{Tr} T)_{i j}$ :

$y_{i j k}=\mu+\operatorname{Tr}_{i}+\varepsilon_{i k}+T_{j}+(\operatorname{Tr} T)_{i j}+\varepsilon_{i j k}$.

For all analyses, significance was considered to be $P<0.05$. The mortality rates were calculated for the five levels of treatment and the significance of differences was tested using the Pearson's chi-square test and Pearson residuals were calculated. Pearson chi-square tests were used to test the alternative hypothesis that an association existed between survived piglets and the different level of treatments.

\section{Results}

\subsection{Milk supplement consumption}

Table 1 shows the total milk supplement and dry milk powder consumption and the average consumption per piglet from 10 days of life till weaning. The total milk supplement consumption per farrowing house was between 1047 and $1572 \mathrm{~L}$. Average milk replacer intakes (liters per pig) from 10th to 27 th days of life were $4.46 \mathrm{~L} \mathrm{pig}^{-1}$ ( $0.725 \mathrm{~kg}$ dry matter).

The price of the dry milk powder is $\sim 2.3 \mathrm{EUR} \mathrm{kg}^{-1}$ $\left(700 \mathrm{HUF} \mathrm{kg}^{-1}\right)$, so the cost per piglet is between 0.85 and 2.13 EUR, differing from the weight percentage of the solution and the consumption, respectively. The price of the prestarter feed is $\sim 1.66 \mathrm{EUR} \mathrm{kg}^{-1}$ (500 HUF). Based on our result, taking into account the cost and the weight development, a $14.5 \%$ weight percentage solution $(1.7 \mathrm{~kg}$ dry milk powder added to $10 \mathrm{~L}$ water) is the most economical dilution. However, as the economic analysis uses approximate calculations, further studies are needed to calculate exact efficiency, which is not the focus of this paper.

Figure 1 shows that consumption of milk replacer varied according to period. There were three isolable parts during the 17 days of consumption. During the first week of the experiments, the average consumption was approximately $25 \mathrm{~L} \mathrm{day}^{-1}$ farrowing ${ }^{-1}$ group $\left(0.08 \mathrm{~L} \mathrm{piglet}^{-1} \mathrm{day}^{-1}\right)$, on the following 6 days, it was $85 \mathrm{~L} \mathrm{day}^{-1}$ farrowing $^{-1}$ group $\left(0.26 \mathrm{~L} \mathrm{piglet}^{-1}\right)$, and on the last 4 days, there was $180 \mathrm{~L}$ of daily consumption in a group $\left(0.56 \mathrm{~L} \mathrm{piglet}^{-1} \mathrm{day}^{-1}\right)$, respectively.

\subsection{Effect of milk supplements on piglet weight mortality and on sow back-fat thickness}

The weights of piglets were individually recorded at birth, at 14 days of age and at weaning (28 days), respectively. 
Table 1. Milk supplement and pre-starter feed consumption in different treatments.

\begin{tabular}{|c|c|c|c|c|c|}
\hline Treatments & Control & MS1 & MS2 & MS3 & MS4 \\
\hline${ }^{1}$ Number of piglets (on day 14 ) & 333 & 333 & 287 & 319 & 330 \\
\hline $\begin{array}{l}\text { Total milk supplement consumption } \\
\text { from 10th to } 27 \text { th life days, L }\end{array}$ & - & 1047 & 1472 & 1572 & 1541 \\
\hline $\begin{array}{l}\text { Average milk supplement consumption } \\
\text { from } 10 \text { th to } 27 \text { th life days piglet }-1, \mathrm{~L}\end{array}$ & - & 3.14 & 5.12 & 4.92 & 4.66 \\
\hline $\begin{array}{l}\text { Average milk supplement } \\
\text { consumption piglet }^{-1} \text { day }^{-1}, \mathrm{~L}\end{array}$ & - & 0.17 & 0.28 & 0.27 & 0.26 \\
\hline $\begin{array}{l}\text { Total milk powder consumption } \\
\text { from } 10 \text { th to } 27 \text { th days, } \mathrm{kg}\end{array}$ & - & 126 & 220 & 267 & 308 \\
\hline $\begin{array}{l}\text { Average milk powder consumption } \\
\text { from } 10 \text { th to } 27 \text { th life days piglet }^{-1}, \mathrm{~kg}\end{array}$ & - & 0.37 & 0.76 & 0.83 & 0.93 \\
\hline $\begin{array}{l}{ }^{2} \text { Total milk powder cost } \\
\text { from } 10 \text { th to } 27 \text { th life days } \text { piglet }^{-1} \text {, EUR }\end{array}$ & - & 0.85 & 1.74 & 1.91 & 2.13 \\
\hline 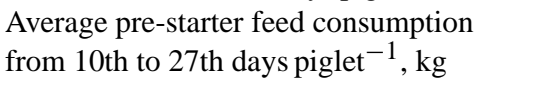 & 0.75 & 0.52 & 0.52 & 0.54 & 0.45 \\
\hline $\begin{array}{l}{ }^{2} \text { Average pre-starter feed cost } \\
\text { from } 10 \text { th to } 27 \text { th days piglet }\end{array}$ & 1.24 & 0.86 & 0.86 & 0.89 & 0.74 \\
\hline
\end{tabular}

${ }^{1}$ We calculate with the number of piglets on day 14 (Table 2).

2 The economic calculations are informative.

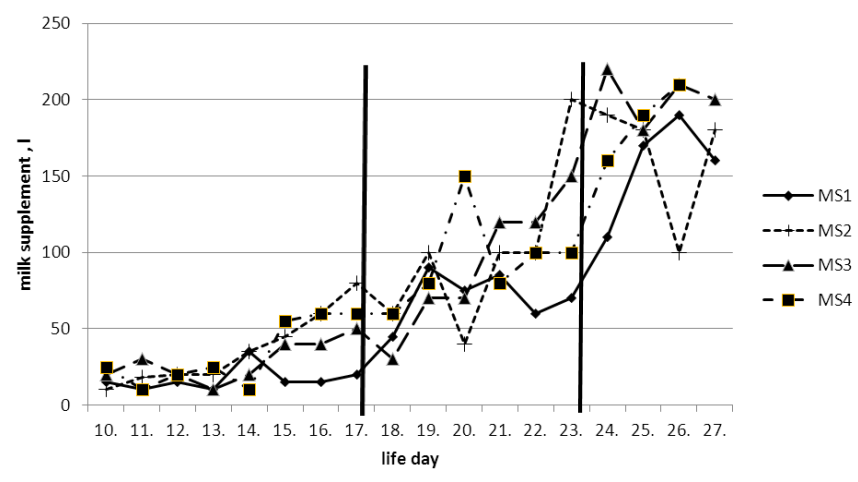

Figure 1. The periodicity of total milk supplement consumption from the 10th day of life until weaning, in different groups $\left(\mathrm{Lday}^{-1}\right)$.

Table 2 shows the piglets' weight with time after birth. Based on Duncan's new multiple range tests, there were no significant differences in birth weight between the control and experimental groups, respectively. However, we found significant differences between the 14-day and weaning weights, subsequently. The chi-square test showed a relationship between mortality and treatments $(P=0.012)$. Based on the Pearson residuals, it can be observed that the C_3 mortality was significantly higher than in the other groups, so the milk supplement significantly reduced mortality compared to the control.
Pre-weaning mortality was significantly different in the groups fed with milk replacer and in the control group $(11.6 \%$ vs. $4.9 ; 5.9 ; 8.9 ; 8.3)$.

We did not find significant differences between litter homogeneity data. However, based on the CV\% of weight, we recorded an improving trend. The MS1, MS3 and MS4 experimental groups became more homogenous, contrary to the weight of the control group at the end of the lactation period (25.34 vs. 20.87; 20.28; 20.29 CV\%).

Table 3 shows the results of the repeated measure mixed effect model. There was a significant difference between the control and the four milk supply feeding $\left(F_{4,1625}=\right.$ $33.42 ; P<0.001)$. There was a time effect $\left(F_{2,3250}=23785\right.$; $P<0.001)$, the milk supply and time interaction effect $\left(F_{8,3250}=39.23 ; P<0.001\right)$.

In examining the reduction of sow back-fat thickness during the suckling period, we found that the reduction was the highest in the control group, although there still were significant differences between the control (C) and MS3 groups (7.61 vs. $5.57 \mathrm{~mm}, P<0.05$ ) (Table 4 ).

\section{Discussion}

Milk is the main energy source for piglets and is, therefore, essential for their growth and survival. In addition to being dependent on the lactational ability of the sow, the actual milk received by an individual piglet is a function of the number of piglets suckling, the size and vigor of those 
Table 2. Effect of milk supplement in different solutions on piglet weight, daily weight gain and mortality.

\begin{tabular}{|c|c|c|c|c|c|c|c|c|c|}
\hline \multicolumn{2}{|c|}{ Treatments } & \multirow{2}{*}{$\begin{array}{r}\begin{array}{r}\text { Number } \\
\text { of piglets }\end{array} \\
363\end{array}$} & \multirow{2}{*}{$\begin{array}{r}\begin{array}{r}\text { Average piglet } \\
\text { weight, } \mathrm{kg}^{1}\end{array} \\
1.40 \mathrm{~g}\end{array}$} & \multirow{2}{*}{$\begin{array}{r}\text { SEM } \\
0.03\end{array}$} & \multirow{2}{*}{$\begin{array}{l}\text { Min } \\
0.49\end{array}$} & \multirow{2}{*}{$\begin{array}{l}\text { Max } \\
2.07\end{array}$} & \multirow{2}{*}{$\begin{array}{l}\text { CV\% } \\
21.01\end{array}$} & \multirow{2}{*}{$\begin{array}{r}\text { Daily weight } \\
\text { gain, g }\end{array}$} & \multirow{2}{*}{$\begin{array}{r}\text { Mortality, } \\
\%^{2} \\
-\end{array}$} \\
\hline Control & C_1 (birth) & & & & & & & & \\
\hline & C_2 $(14 d)$ & 333 & $4.11 \mathrm{f}$ & 0.06 & 1.10 & 6.77 & 25.06 & 0.20 & $8.2 b$ \\
\hline & C_3 (weaning) & 321 & $7.38 \mathrm{c}$ & 0.08 & 2.01 & 12.29 & 25.34 & 0.23 & $11.6 \mathrm{a}$ \\
\hline \multirow{3}{*}{$\begin{array}{l}\text { Milk supplement } \\
\text { in } 10.7 \% \text { solution }\end{array}$} & MS1_1 (birth) & 347 & $1.41 \mathrm{~g}$ & 0.03 & 0.51 & 2.32 & 20.86 & - & - \\
\hline & MS1_2(14d) & 333 & $4.25 \mathrm{e}$ & 0.05 & 1.66 & 7.48 & 22.59 & 0.20 & $4.0 \mathrm{~b}$ \\
\hline & MS1_3 (weaning) & 330 & $8.24 b$ & 0.07 & 2.51 & 12.85 & 20.87 & 0.29 & $4.9 \mathrm{~b}$ \\
\hline \multirow{3}{*}{$\begin{array}{l}\text { Milk supplement } \\
\text { in } 13 \% \text { solution }\end{array}$} & MS2_1 (birth) & 305 & $1.52 \mathrm{~g}$ & 0.03 & 0.66 & 2.46 & 23.03 & - & - \\
\hline & MS2_2(14d) & 287 & $4.61 d$ & 0.06 & 1.67 & 7.36 & 23.64 & 0.22 & $5.9 \mathrm{~b}$ \\
\hline & MS2_3 (weaning) & 287 & $8.26 b$ & 0.08 & 2.52 & 12.57 & 25.06 & 0.26 & $5.9 \mathrm{~b}$ \\
\hline \multirow{3}{*}{$\begin{array}{l}\text { Milk supplement } \\
\text { in } 14.5 \% \text { solution }\end{array}$} & MS3_1 (birth) & 347 & $1.48 \mathrm{~g}$ & 0.03 & 0.48 & 2.25 & 20.95 & - & - \\
\hline & MS3_2(14d) & 319 & $4.66 \mathrm{~d}$ & 0.06 & 1.15 & 7.72 & 22.75 & 0.23 & $8.0 \mathrm{~b}$ \\
\hline & MS3_3 (weaning) & 316 & $9.17 \mathrm{a}$ & 0.08 & 2.53 & 15.08 & 20.28 & 0.32 & $8.9 b$ \\
\hline \multirow{3}{*}{$\begin{array}{l}\text { Milk supplement } \\
\text { in } 16.6 \% \text { solution }\end{array}$} & MS4_1 (birth) & 347 & $1.40 \mathrm{~g}$ & 0.03 & 0.58 & 2.22 & 23.57 & - & - \\
\hline & MS4_2(14d) & 330 & $4.76 \mathrm{~d}$ & 0.06 & 1.70 & 5.61 & 22.80 & 0.24 & $4.9 \mathrm{~b}$ \\
\hline & MS4_3 (weaning) & 318 & $8.38 b$ & 0.07 & 4.47 & 13.15 & 20.29 & 0.26 & $8.3 b$ \\
\hline
\end{tabular}

Table 3. The results of the repeated measure mixed effect model.

\begin{tabular}{lrrrrr}
\hline Denomination & SS & Df & MS & $F$ value & $P$ value \\
\hline Milk supply & 372 & 4 & 92.97 & 33.42 & $P<0.001$ \\
Residuals (milk supply) & 4520 & 1625 & 2.78 & - & - \\
Time & 38711 & 2 & 19356 & 23785 & $P<0.001$ \\
Milk supply $\times$ time & 255 & 8 & 32 & 39.23 & $P<0.001$ \\
Residuals (time) & 2645 & 3250 & 1 & - & - \\
\hline
\end{tabular}

SS: sum of square, Df: degree of freedom, MS: mean square

piglets and the stage of lactation. Nevertheless, sows cannot produce enough milk to sustain the optimal growth of their litters. This inability is seen as of approximately 8 to $10 \mathrm{~d}$ of age and the situation worsens as lactation progresses. This problem was exacerbated in recent years with the introduction of hyperprolific sow lines (Farmer, 2013; Kyriazakis et al., 2006).

Our result suggested that piglets fed with supplemental milk replacer during lactation had better growth rates. However, while there were no significant differences in birth weight between the control and experimental groups, we found significant differences between the 14-day weights and the weaning weights, subsequently. Supplemental milk replacer resulted in a significant increase in weaning weights.

Selection for sow ability to give birth to a higher number of piglets has led to an increased within-litter variation in piglet birth weights. Piglets with low birth weights grow more slowly than piglets with higher live weights at birth. Variation in piglet weights within a group at weaning can affect the productivity of commercial pig production systems, particularly those implementing all-in all-out animal management. It is widely accepted that light pigs at birth required number of days to reach the same market weight than did their heavier littermates. The strong positive relationship between weaning weight and the growth of pigs postweaning suggests that there are considerable economic advantages associated with increasing the weaning weights of pigs (Gondret et al., 2005a, b; King et al., 1997; Vaclavkova et al., 2012; Wolter et al., 2002).

There were no statistically significant differences between litter homogeneity data. However, based on the CV\% of weight, an improving trend has been noted: three experimental groups became more homogenous, in contrast with the weight of the control group at the end of lactation period.

In our experiments, pre-weaning mortality was significantly different in the groups fed with milk replacer than in the control group.

Therefore, providing piglets with supplemental liquid milk during lactation has a significant effect on growth performances, can increase weaning weights, reduce pre-weaning mortality and tend to increase the uniformity of a litter. 
Table 4. The effect of feeding pigs with milk supplement on sow back-fat thickness $(\mathrm{mm})$ change during the suckling period (number of sows $=30$ in every group).

\begin{tabular}{|c|c|c|c|c|c|c|c|c|c|c|}
\hline \multirow[t]{2}{*}{ Milk supplement treatments } & \multicolumn{2}{|c|}{$\mathrm{C}$} & \multicolumn{2}{|c|}{ MS1 } & \multicolumn{2}{|c|}{ MS2 } & \multicolumn{2}{|c|}{ MS3 } & \multicolumn{2}{|c|}{ MS4 } \\
\hline & Mean & SEM & Mean & SEM & Mean & SEM & Mean & SEM & Mean & SEM \\
\hline Farrov & 21.70 & 0.70 & 21.28 & 0.65 & 20.13 & 0.76 & 22.10 & 1.06 & 19.61 & 0.85 \\
\hline $14 \mathrm{~d}$ & 17.26 & 0.75 & 16.06 & 0.68 & 14.83 & 0.63 & 20.93 & 0.93 & 16.26 & 0.82 \\
\hline Weaning & 14.09 & 0.67 & 13.96 & 0.61 & 13.23 & 0.81 & 16.53 & 0.87 & 13.55 & 0.77 \\
\hline Reduction from farrowing to weaning & $7.61^{\mathrm{a}}$ & 0.48 & $7.32^{\mathrm{ab}}$ & 0.53 & $6.90^{\mathrm{ab}}$ & 0.58 & $5.57^{\mathrm{b}}$ & 0.48 & $6.06^{\mathrm{ab}}$ & 0.51 \\
\hline
\end{tabular}

a,b Within a row, means with different superscripts are significantly different $(P<0.05)$ using the Duncan test.

There is a substantive body of evidence to show that rapid growth achievement before and after weaning (through the use of high-quality diets and excellent management) will have a positive residual effect throughout the remaining growth period through to slaughter. Compensatory growth following poor post-weaning performance is not evident under practical production conditions, and investment in maximizing early growth is handsomely returned at slaughter in terms of superior daily gain and feed efficiency through the grow-out period (Kyriazakis et al., 2006).

Further research should be done on the effect of milk supplement on the behavior and welfare of the piglets, as well as on their performance until slaughter.

In primiparous sows, a sufficient layer of back fat was a guarantee of fertility also for the second parturition. Furthermore, there is a significant effect of back-fat thickness on litter size and the scheduling of first insemination (Cechova and Tvrdon, 2006).

In examining the reduction of sow back-fat thickness, while we found that the reduction was the highest in the control group, there were still significant differences between the control and MS3 group during the suckling period.

Further studies are planned to examine the subsequent reproduction performances of the sows and the female piglets, which were utilized later as breeding sows from the experimental and control groups, respectively. We record the reproductive data, measure the back-fat thickness of young sows and follow up their first date of insemination, fertility and litter sizes.

In this study, we provided piglets with milk supplement in different solutions $(10.7 ; 13$; 14.5 vs. 16.6 weight percentage). Based on our results, the 14.5 weight percentage solution $(1.7 \mathrm{~kg}$ dry milk powder added to $10 \mathrm{~L}$ water) is the best from the standpoint of weaning weight $(9.17 \mathrm{~kg})$, litter homogeneity $(20.28 \mathrm{CV} \%)$ and the reduction of sow back-fat thickness during lactation $(5.57 \mathrm{~mm})$. According to the preliminary calculations, this solution is economical; however, further investigations are needed to calculate the exact economic indicators.

Consequently, providing piglets with supplemental liquid milk replacer has an identifiable effect on growth performances, increases weaning weight, reduces pre-weaning mortality, has a positive effect on litter homogeneity and reduces sow leakage during lactation. Our results serve as the bases for further reproductive and economic research in connection with feeding liquid milk replacer in the farrowing house.

Acknowledgements. We are thankful to Ferenc Marmoly, the manager of the pig farm of Hajdúböszörményi Mezőgazdasági Zrt. Thanks to the workers of the pig farm and to PhD student Nikolett Csizmár for helping us with the manual labor.

Edited by: S. Maak

Reviewed by: two anonymous referees

\section{References}

Allen, A. D. and Lasley, J. F.: Milk production of sows, J. Anim. Sci., 19, 150-155, 1960.

Azain, M. J., Tomkins, T., Sowinski, J. S., Arentson, R. A., and Jewell, D. E.: Effect of supplemental pig milk replacer on litter performance: Seasonal variation in response, J. Anim. Sci., 74, 2195-2202, 1996.

Cechova, M. and Tvrdon, Z.: Relationships between backfat thickness and parameters of reproduction in the Czech Large White sows (short communication), Arch. Anim. Breed., 49, 363-369, 2006.

Clowes, E. J., Aherne, F. X., Foxcroft, G. R., and Baracos, V. E.: Selective protein loss in lactating sows is associated with reduced litter growth and ovarian function, J. Anim. Sci., 81, 753-764, 2003.

Farmer, C.: Review: Mammary development in swine: effects of hormonal status, nutrition and management, Can. J. Anim. Sci., 93, 1-7, 2013.

Gondret, F., Lefaucheur, L., Louveau, I., and Lebret, B.: The longterm influences of birth weight on muscle characteristics and eating meat quality in pigs individually reared and fed during fattening, Arch. Anim. Breed., 48, 68-73, 2005a.

Gondret, F., Lefaucheur, L., Louveau, L., Lebret, B., Pichodo, X., and Le Cozler, Y.: Influence of piglet birth weight on postnatal growth performance, tissue lipogenic capacity and muscle histological traits at market weight, Livest. Prod. Sci., 93, 137-146, 2005 b. 
Johansen, M., Alban, L., Kjaersgard, H. D., and Baekbo, P.: Factors associated with suckling piglet average daily gain, Prev. Vet. Med., 63, 91-102, 2004.

King, R. H., Mullan, B. P., Dunshea, F. R., and Dove, H.: The influence of piglet body weight on milk production of sows, Livest. Prod. Sci., 47, 169-174, 1997.

Knecht, D., Srodon, S., and Duziuski, K.: The impact of season, parity and breed on selected reproductive performance parameters of sows, Arch. Anim. Breed., 58, 49-56, 2015.

Kyriazakis, I., Whittemore, C. T., and Whittemore, C. T.: Whittemore's science and practice of pig production, 3rd edn., Blackwell Pub., Oxford, UK; Ames, Iowa, xvi, 685 pp., 2006.

Mendiburu, F.: agricolae: Statistical Procedures for Agricultural Research. R package version 1.1-8, available at: http://CRAN. R-project.org/package=agricolae, last access: 12 October 2014.

Mitchell, A. D., Ramsay, T. G., Caperna, T. J., and Scholz, A. M.: Body composition of piglets exhibiting different growth rates, Arch. Anim. Breed., 55, 356-363, 2012.

Quiniou, N., Dagorn, J., and Gaudre, D.: Variation of piglets birth weight and consequences on subsequent performance, Livest. Prod. Sci., 78, 63-70, 2002.

Ramanau, A., Kluge, H., Spilke, J., and Eder, K.: Supplementation of sows with L-carnitine during pregnancy and lactation improves growth of the piglets during the suckling period through increased milk production, J. Nutr., 134, 86-92, 2004.
R Core Team R: A language and environment for statistical computing, R Foundation for Statistical Computing, Vienna, Austria, ISBN 3-900051-07-0, available at: http://www.R-project.org/, last access: 12 October 2014.

Renaudeau, D. and Noblet, J.: Effects of exposure to high ambient temperature and dietary protein level on sow milk production and performance of piglets, J. Anim. Sci., 79, 1540-1548, 2001.

Skorjanc, D., Brus, M., and Potokar, M. C.: Effect of birth weight and sex on pre-weaning growth rate of piglets, Arch. Anim. Breed., 50, 476-486, 2007.

Spencer, J. D., Boyd, R. D., Cabrera, R., and Allee, G. L.: Early weaning to reduce tissue mobilization in lactating sows and milk supplementation to enhance pig weaning weight during extreme heat stress, J. Anim. Sci., 81, 2041-2052, 2003.

Vaclavkova, E., Danek, P., and Rozkot, M.: The influence of piglet birth weight on growth performance, Res. Pig Breed., 6, 59-61, 2012.

Wolter, B. F., Ellis, M., Corrigan, B. P., and DeDecker, J. M.: The effect of birth weight and feeding of supplemental milk replacer to piglets during lactation on pre-weaning and post-weaning growth performance and carcass characteristics, J. Anim. Sci., 80, 301308, 2002. 